\title{
CORRELATION OF BODY IMAGE AND EATING PATTERN AMONG HIGH SCHOOL STUDENTS IN DEMAK, CENTRAL JAVA
}

\author{
Rio Ade Atmoko, Umi Aniroh, Zumrotul Choiriyyah \\ Universitas Ngudi Waluyo, Ungaran, Central Java
}

\begin{abstract}
Background: Body image is a multidimensional construct central to emotional well-being in which the attitudinal components satisfaction with body size. There is a lack of data on the association between body image and eating pattern in Demak, Central Java. This study aimed to analyze the correlation of body image and eating pattern among high school students in Demak, Central Java.

Subjects and Method: This was a cross sectional study carried out at High School I Demak, Central Java. A total of 93 students was selected for this study using simple random sampling. The dependent variable was eating pattern. The independent variable was body image, consisting of physical attractiveness, body size satisfaction, appraisal on body image compared with others, and effort to improve body image. Body image were measured using questionnaire. The other data were collected by questionnaire and analyzed using chisquare.

Results: A total of $51.6 \%$ high school students had positive body image and $48.4 \%$ had negative body image. A total of $51.6 \%$ had poor eating pattern and $48.4 \%$ had good eating pattern. Body image was positively associated with eating pattern.

Conclusion: Positive body image is associated with good eating pattern.
\end{abstract}

Keywords: body image, eating pattern, student

Correspondence:

Zumrotul Choiriyyah. Universitas Ngudi Waluyo, Ungaran, Semarang, Central Java.

Email: zumrotulnwu@gmail.com. Mobile: 087889834959.

The 5th International Conference on Public Health Best Western Premier Hotel, Solo, Indonesia, February 13-14, 2019| 232 https://doi.org/10.26911/theicph.2019.02.42 